ТЕТЯНА КОТИК, доктор педагогічних наук, професор, кафедра фахових методик і технологій початкової освіти, ДВНЗ "Прикарпатський національний університет імені Василя

Стефаника", Україна

ORCID ID 0000-0001-8213-8318 tetiana.m.kotyk@pu.if.ua

\title{
МЕТОДОЛОГІЧНІ ЗАСАДИ ПЕРІОДИЗАЦІЇ СТАНОВЛЕННЯ І РОЗВИТКУ ПЕДАГОГІЧНИХ НАУК ТА ДОСЛІДЖУВАНИХ ПРОБЛЕМ І ЯВИЩ
}

\author{
TTETIANA KOTYK, Doctor of Pedagogical Sciences, Professor of the \\ Department of Professional Methods and Techniques of Primary \\ Education, Vasyl Stefanyk Precarpathian National University, Ukraine
}

\section{METHODOLOGICAL PRINCIPLES OF PERIODIZATION OF THE FORMATION AND DEVELOPMENT OF PEDAGOGICAL SCIENCES AND RESEARCH PROBLEMS AND PHENOMENA}

\begin{abstract}
У статті висвітлено методологічні орієнтири для здійснення періодизації становлення і розвитку педагогічної галузі та досліджуваної педагогічної проблеми. Послуговуючись історико-генетичним і теоретичним аналізом філософської, методологічної та педагогічної наукової літератури, засвідчено тісний взаємозв'язок загальнофілософської періодизації розвитку суспільства і загальнонаукової періодизації розвитку знання; здійснено інтерпретацію основних положень синергетичного підходу для періодизації розвитку педагогічних наук і педагогічних явищ.
\end{abstract}

Ключові слова: методологія педагогіки, періодизація становлення й розвитку педагогічних наук і проблем, положення синергетичного підходу.

Summary. The article deals with the methodological guidelines for the periodization of the formation and development of the pedagogical sphere and the pedagogical problem under study. Using the historical genetic and theoretical analysis of the philosophical, methodological and pedagogical special literature, a close correlation of the general philosophical periodization of the development of society and the general scientific periodization of the development of knowledge is attested;

(c) Т. Котик the basic provisions of the synergistic approach for periodization of the development of pedagogical sciences and pedagogical phenomena have been interpreted, which allowed us to reach the following conclusions. We view science as a controlled system that is hierarchically subordinated to a higher order system, i.e. the social system that puts forward certain goals and objectives for science and its individual parts. The social systems of individual nations are elements of a supersystem, i. e. the human community. The stability of a system is based on the functioning of all its elements in a time space. Therefore, the periodization of Ukrainian linguistics didactics as an independent branch of pedagogical science in connection with the general philosophical periodization of the development of society, the general scientific periodization of the development of science, and the general periodization of the development of pedagogy have been made, since each of the systems of higher order affects the development of the system. A synergistic approach to the interpretation of the development of pedagogical sciences and phenomena helps to understand the process of their formation and development through the concept of synergy, which leads to understanding the mechanism and internal factors of the development of the subject of study and to find the initial limit of its periodization.
Key words: methodology of pedagogy, periodization of formation and development of pedagogical sciences and problems, principles of synergistic approach.

Мета: висвітлити методологічне знаряддя для здійснення періодизації становлення і розвитку педагогічної галузі або педагогічного явища.

Постановка проблеми в загальному вигляді. Періодизація розвитку - фундаментальна проблема будь-якої науки, у тому числі й педагогіки, оскільки педагогічне явище, що розглядається з позиції діахронії, у часовій послідовності, потребує визначення хронологічних меж й обгрунтування саме такого часового співвіднесення. Через окреслення періодів розвитку і закономірностей переходу від одного до наступного стане розв'язаною проблема визначення рушійних сил i механізму розвитку педагогічного явища. Крім того, усіляке уявлення про рушійні сили розвитку можна перевірити на основі правильно вирішеного питання періодизації.

Під періодизацією розуміємо логічний поділ часу існування педагогіки, або окремих іiї галузей, явищ на відносно самостійні окремі відтинки - періоди, яким притаманні якісні новоутворення і які водночас відображають як загальні закономірності розвитку суспільства, так і специфічні за своїм змістом. Виокремлюють періоди на підставі важливих об'єктивних показників переходу від 
одного періоду до другого. Неоднорідність таких показників і переходів зумовлює наявність етапів і стадій розвитку в межах періодів.

Аналіз досліджень і публікацій. У 80-х рр. ХХ ст. зроблено спробу визначити критерії розвитку освіти в межах радянської педагогіки. Вирішальну роль відводилась зовнішнім чинникам, що зумовлювали розвиток не лише освіти, а й політики, економіки, культури радянського суспільства, -це були рішення партійних з'їздів і партійно-урядових постанов про школу (Равкин, 1984).

Так, Б. Ступарик здійснив періодизацію розвитку шкільної освіти й педагогічної думки в Галичині (XVIII - початок XX ст.) з урахуванням не лише соціально-економічних потреб суспільства, але і змін, що відбувалися у процесі національнокультурного відродження, обстоюючи думку, що особливості еволюції досліджуваної проблеми викликані змінами в суспільному житті, тому періодизація розвитку шкільництва відповідає періодизації національнокультурного відродження (Cmynaрик, 1995, с. 17-37).

Водночас методологи історії педагогіки наголошували, що періодизацію необхідно здійснювати з урахуванням як загальних закономірностей розвитку громадського життя, так й істотних моментів генези досліджуваної проблеми, визначальних етапів у розвитку систем, структурним елементом яких $є$ означена проблема (Струманський, 1996, с. 145).

У ракурсі таких вимог здійснено парадигмальний підхід до періодизації розвитку системи освіти та педагогічної думки Східноукраїнського регіону (XX ст.), у межах якого зовнішній вплив на систему розглядали значно ширше (Курило, 2000). До значущих чинників В. Курило відніс: світові тенденції розвитку освіти; процеси, що відбувалися в Росії та Радянському Союзі, системі народної освіти України; соціальноекономічні умови розвитку країни й регіонів. Науковець підійшов до аналізу процесу розвитку діалектично й тому подав загальну періодизацію процесу розвитку системи освіти XX ст. у тісному зв'язку з періодизацією системи освіти Східноукраїнського регіону. Водночас періодизацію, в основу якої покладено визначні події історії розвитку суспільства (зовнішні), учений не вважав перспективною для глибокого дослідження основної проблеми. Сутність розвитку системи освіти він обумовив іiї внутрішніми чинниками, тому вважав за необхідне в періодизації ураховувати найсуттєвіші характеристики системи освіти, а саме: спрямованість цілей; зміст процесу навчання; характер функцій педагога й учня; доступність освіти, зв'язок 3 наукою, які разом склали парадигму ії розвитку. Відповідно саме зміна парадигм й обумовила розподіл історії розвитку системи освіти і педагогічної думки на етапи: 1880-1917 pp., 1917 - середина 30-х pp., середина 30-х - кінець 80-х рр., 90-ті pp. - теперішній час.

У дослідженні розвитку національної педагогічної думки в Україні О. Сухомлинська розкрила власне бачення періодизації розвитку означеного феномена, послуговуючись культурно-антропологічним та цивілізаційним підходами до висвітлення проблеми. У контексті європейської цивілізації вона виокремила український культурний простір і ті риси, що притаманні саме українській педагогічній думці як частині європейської традиції. Науковець розглядала педагогічні явища в тісному зв'язку з розвитком людської цивілізації, пов'язувала розвиток педагогіки із загальносуспільною періодизацією (Сухомлинська, 2002).

С. Попиченко досліджувала проблему розвитку теорії і практики дошкільного виховання кінця XIX початку ХХ ст. (Попиченко, 1998). Початок запропонованої періодизації вчена співвідносила з відкриттям перших суспільних дошкільних установ в Україні, а ії кінець позначила 1917 р., пояснюючи це тим, "що саме в цьому році кардинально змінюються соціально-економічні, національно-політичні та педагогічні умови, що обумовлюють діяльність дитячих закладів" (Попиченко, 1998, c. 4).

Логічне продовження означеної періодизації міститься у праці Л. Батліної, де аналіз розвитку суспільного дошкільного виховання в Україні представлений 1917-1941 роками. У межах означеного часу дослідниця виокремила етап становлення (19171926 рр.) та етап розвитку (1926-1941 pp.) суспільного дошкільного виховання в УРСР, умежах яких визначає внутрішні етапи.

У багатьох педагогічних вислідах учені здійснюють періодизацію ста- новлення і розвитку досліджуваних проблем та явищ, натомість не завжди обумовлюють чинники й обгрунтовують умови, що зумовили такий поділ.

Виклад основного матеріалу дослідження. Суттєвою рисою філософського й наукового аналізу сучасного суспільства $\epsilon$ розгляд його не як сукупності окремих систем, а цілісного організму, здатного розвиватися тільки в тісному взаємозв'язку всіх елементів - філософії, науки, мистецтва, виробництва, моралі, традицій тощо.

У ХХ ст. змінився філософський підхід до історичної періодизації існування людської спільноти: замість виокремлення культурних цивілізацій ідеться про контроверзу модерн - постмодерн. Однозначного розуміння сутності цих понять і межі, що їх розділяють, у філософії, соціології, культурології ще не вироблено, але, починаючи з 50 -х років XX ст. у соціології США, пізніше Західної Свропи, а у 80-90-х роках ХХ ст. і в радянській, і пострадянській філософії аналіз сучасного культурного стану суспільства здійснювали 3 погляду протистояння модерну i постмодерну. Характеристику даного підходу знаходимо у працях П. Козловськи (Козловски, 1997, с. 21). На його думку, для епохи постмодернізму характерним $є$ пошук утраченої людством гармонії у протистоянні раціоналізму й ірраціоналізму епохи модерну. Ж.-Ф. Ліотар обумовлює характерні особливості епохи постмодерну значним впливом на всі сфери життя суспільства таких нових наукових галузей, як кібернетика, інформатика, а також розвитком штучних мов. Українські філософи (В. Лук'янець, О. Соболь) розгядають постмодерн як стан цивілізації з виснаженими життєвими силами порівняно 3 епохою Просвітництва, а від модерну його відрізняють "відчуття зростаючого катастрофізму, тривожне очікування соціокультурного колапсу, фундаментальна втрата життєстверджувальної культурної орієнтації" (Лук'янецьь \& Соболь, 1998, с. 228).

Порівнюючи особливості періодів модерн - постмодерн загальносуспільної періодизації з характеристиками періодів класична - некласична - постнекласична загальнонаукової періодизації, Л. Дротянко дійшов висновку, що "і некласична наука, і некласична філософія нале- 
жать до епохи модерну, оскільки їм притаманний спільний стиль мислення, зміна орієнтацій стосовно об'єктів дослідження, введення суб'єкта в процес дослідження" (Дротянко, 1999, с. 45); і філософія, i наука, і мистецтво ставляться до природи як до невичерпного джерела багатства, а суспільство переживає епоху індустріалізму. Лише із середини XX ст., коли загрозливо прозвучали прогнози на майбутне у зв'язку з руйнівною діяльністю людства, почалося "глибинне переосмислення підвалин світовідчуття та світорозуміння, усвідомлення причетності людини до явищ, що відбуваються в універсамі.., тобто починає формуватися ноосферне мислення" (Дротянко, 1999, с. 46). На підставі дослідження суспільного й культурного стану епохи постмодерну, П. Козловськи констатував, що цей період розвитку людства змінив ціннісні орієнтири знання, і тому "детальне викладання природничих дисциплін, результати яких швидко старіють, ... повинне бути скорочене на користь більш орієнтованої на культуру освіти, спрямованої на оволодіння інституціональними принципами. Це нове співвідношення між гуманітарними і природничими науками, між орієнтованими на культуру i зосередженими на техніці завданнями освіти відповідає тенденціям розвитку суспільства від такої його стадії, на якій усе спрямовано на отримання конкретного матеріального результату, до такої його стадії, на якій першочергове значення має культура" (Козловски, 1997, с. 111).

Отже, в епоху постмодерну все більше визнається важливість буття не лише економіки, політики, соціальної сфери, але й національних культур, відтак характер науки, освіти підпорядковується загальним тенденціям існування суспільної системи, що й зумовило у 80-90 роках XX ст. підвищений інтерес до національної мови, культури українського народу, а у зв'язку з цим - стрімкий розвиток таких галузей педагогічної науки, як українська народна педагогіка, українська лінгводидактика.

На думку багатьох дослідників, сучасна наука ввійшла до періоду постнекласичних трансформацій, що означено більш глибоким зануренням її в об'єктивний світ і принциповим розширенням можливостей людини завдяки вдосконаленню техніки. Відповідні риси простежує- мо й у сучасному стані вітчизняної педагогіки.

У постнекласичній науці визначився новий напрям дослідження механізмів еволюції та самоорганізації складних нелінійних і відкритих систем, який було названо Г. Хакеном синергетикою (Хакен, 2000) (від грецької - "який діє спільно"), що, на наш погляд, досить адекватно відображає сутність даної теорії. Її прихильники вважають, що більшість досліджуваних систем відкриті, самоорганізовані, їх функціонування здійснюється під впливом певних універсальних законів.

Ідейними зачинателями виведення таких законів і розкриття механізму розвитку науки вважають Т. Куна, I. Лакатоса, К. Поппера, П. Фейерабенда, котрі, вивчаючи методологію науки, переосмислили підхід до логіко-методологічного аналізу розвитку наукового знання. Зокрема, американський філософ Т. Кун обстоював думку про те, що історія розвитку науки - це процес зміни іiі концептуальних структур, які він назвав парадигмами. У межах кожної такої парадигми він виокремлював стан розвитку "нормальної науки" та стан наукової революції, упродовж якої і відбуваються "деструктивно-конструктивні" зміни в парадигмі (Кун, 1977, с. 27-93). Під "нормальною наукою" учений розумів діяльність науковців, спрямовану на вирішення дрібних проблем. Ретельна підготовка до їх вивчення з урахуванням певних правил відображала "майстерність" дослідника. Правила діяльності науковців для "розв'язання головоломок", повинна визначати існуюча парадигма $(К y н, 1977$, c. 60 61). Етапові існування "нормальної науки" притаманна поява аномалій, що веде до іншого етапу в розвитку знання - наукової революції. Знання, набуті в межах попередньої парадигми, відкидаються у процесі їі заміни, що зазнає наукової революції, і нова парадигма $є$ шляхом до "нормальної науки". Обов'язковою умовою виступає визнання парадигми доведеною всіма членами "наукової спільноти" певної дисципліни (Кун, 1977, с. 234).

T. Кун уважав, що розвиток науки пов'язаний іiї внутрішньою логікою, а не зумовлений зовнішніми обставинами. Не випадково кунівську концепцію зміни наукових парадигм I. Пригожин та I. Стенгерс назвали однобічною, оскільки, на їхнє переконання, розвиток науки викликаний не лише ії внутрішніми потребами, а й впливом культурного середовища: "Посилання на культурне становище, звичайно, не може бути повною відповіддю, але й ігнорувати культурний фон також не видається можливим. Ми не можемо не враховувати складні відносини між "внутрішніми" і "зовнішніми" детермінантами виробництва наукових понять" (Пригожин, 1986, c. 382).

Погоджуючись в основному 3 кунівською теорією розвитку наукового знання, П. Фейерабенд категорично заперечував відокремлення етапів "нормальної науки" і наукової революції: у процесі реального розвитку науки вони тісно переплітаються, і тому їх неможливо розмежувати в часі (Фейерабенд, 1986, с. 76); учений не визнавав кумулятивістського принципу в розвитку знань, доводячи, що будь-яка нова теорія не сумісна зі старою. К. Поппер, навпаки, вважав безперервне зростання наукового знання істотним для раціонального та емпіричного характеру наукового пізнання, і якщо наука перестане рости, наголошував філософ, вона втратить такий зміст (Попnер, 1975, с. 325). Прихильником висловлених ідей залишався Х. Патнем, доводячи необхідність кумулятивного характеру розвитку наукового знання: "... незважаючи на той факт, що наукові постулати зазвичай є хибними, наукове пізнання розвивається кумулятивно в тому розумінні, що навіть якщо хороша наукова теорія не $\epsilon$ в точності правильною, розумно апроксимована теорія звичайно $є$ правильною й у кінцевому результаті виявляється стійкою частиною наших основ пізнання" (Патнэм, 1998, c. 148).

Отже, кунівська модель подає розвиток науки як цілісний процес, який складається з еволюції знання, некумулятивних стрибків та діяльності членів наукової спільноти, що відбувається в межах єдиної парадигми розвитку наукового знання. Робочий стан парадигми - це теоретичні й експериментальні напрацювання науковців. Розвиток системи супроводжується незначними змінами параметра порядку під впливом трансформацій, що відбуваються на мікрорівні. Досягнення критичного значення змін приводить до якісного перетворення всієї сис- 
теми, тобто з мікрооб'єктів виникають мікроструктури, які сприяють перетворенням у мікроорганізмах. Тому закономірно, що в основі розвитку системи закладений принцип колової причинності, "де, з одного боку, параметри порядку визначають рух окремих частин системи, а 3 іншого боку, окремі частини системи, у свою чергу, визначають дію параметрів порядку" (Хакен, 2000, c. 37).

Таким чином, ідеться про саморозвиток системи, де кризи - це не просто "постаріння" парадигми, а їі самогенеруюче сходження до свого апогею, до виявлення нових проблем, розв'язання яких уже неможливе у старих межах. Усе це зумовлює наукову революцію як закономірне завершення етапу "нормальної науки", у якому знання визрівало для потрібного оновлення, прориву в майбутнє. Концептуальні засади даної теорії склали філософські підстави синергетики - руху в науці, що розкриває механізми її становлення і розвитку.

Основними поняттями синергетики виступають хаос, самоорганізація, кооперативна дія, детермінований хаос, порядок, біфуркація тощо.

Проілюструємо, як можна інтерпретувати становлення і розвиток такої педагогічної галузі науки, як українська дошкільна лінгводидактика, через поняття синергетики. Ми розглядаємо науку як систему знань і систему діяльності з отримання i використання знань, що разом складають певну науково-інформаційну систему, яка окреслюється межами конкретної науки і характеризується притаманними їй способами функціонування. Систему наукового знання створює своєю діяльністю вся сукупність учених даної галузі науки - наукове товариство, або "кооператив", де діють окремі його представники - учені. У зв'язку 3 цим синергетика розглядає наукову інформацію як соціокультурне явище, яке презентує хаос знань, набутих багатьма вченими. Проте для кожного зосібна наукова інформація з його спеціальності представляє певну когнітивну структуру, а відтак "хаос" перетворюється на "упорядкований хаос". Цей упорядкований, або детермінований хаос і $є$ науково-інформаційною структурою, у якій "хаос" - це зіткнення наукової інформації окремих учених у межах структури певної галузі науки. Саме в такому ракурсі розглядаємо наукову інформацію як продукт кооперативної дії.

3 погляду синергетики саме хаос, що несе в собі різні потенції, створює можливість самоорганізації, або переходу хаосу в порядок, впорядковану структуру. На наше переконання, перехід з безструктурного, однорідного хаосу до самоорганізуючої системи в межах української дошкільної лінгводидактики відбувався за сценарієм, який опишемо мовою синергетики. Локальна квазістабільна структура, поступово збільшуючись, почала конкурувати 3 іншою просторовою структурою. На основі зміни зовнішніх умов квазіструктура опинилась у пункті виходу з режиму хаосу. Зовнішніми в даному випадку виступили соціально-культурні (збільшення інтересу до національної культури) і політичні (здобуття Україною незалежності) чинники. Крім того, час перебування науково-інформаційної квазіструктури у стані хаосу ми можемо охарактеризувати як не надто тривалий, інакше все могло обернутися подальшою деструкцією.

У процесі становлення самоорганізації спостерігаються істотні зміни в системі наукового знання. За висновками О. Князєвої, "швидкість зростання наукової інформації пропорційна не числу носіїв інформації, а числу продуктивних взаємодій між ними. Це неодноразове зіткнення інформаційних потоків приводить до інформаційного вибуху" (Князева, 1996, с. 114). Процес творення наукового знання і $€$ самоорганізацією науково-інформаційної системи, що здійснюється не просто як "добудова одного поверху будівлі іншим", а як "автоноезис", тобто як самоускладнення існуючих частин.

Отже, використання універсального (у теперішній час) синергетичного підходу в дослідженні становлення і розвитку науки дає змогу збагнути, що остання має "людське обличчя", тобто в еволюції науки, крім парадигмального розвитку знання, існує ще й рівень наукової діяльності вчених - "наукової спільноти".

Синергетичний підхід надає можливість визначити об'єктивні критерії виокремлення періодів у розвитку науки, серед яких: зміна світосприйняття науковою спільнотою; застосування нових підходів у дослід- ницькій діяльності й оцінці ії результатів; поява комплексу понять, логічно не пов'язаних з наявними раніше.

3 проблемою періодизації історії становлення і розвитку педагогічної науки, проблеми або явища тісно пов'язана інша - визначення початкової межі такої періодизації. Тому доцільним вважаємо перетворити іiі на низку запитань, відповідь на які й буде послідовним розв'язанням означеної проблеми.

Зазначимо, що метою роботи 3 визначення періодизації $\epsilon$ не дослідження процесу походження, який уміщує праісторію й передісторію, передумови й підгрунтя його появи, - це суто історична проблема. Потрібно встановити початковий стан виникнення того предмета, кінцевий стан якого на сучасному етапі його розвитку нам уже відомий.

Визначаючи методологічні орієнтири для дослідження педагогічних систем, Г. Щедровицький зазначав, що кожний елемент системи можна представити як певне явище і обов'язково з усіма зв'язками, у яких воно існує всередині системи, тобто функціонує. Таке функціонування наділяє явище відповідними властивостями, що й характеризує його як елемент означеної системи. Але функція - це лише форма прояву зв'язку, вона не має власного.

Відтак до кожної педагогічної теорії слід підходити як до певного матеріалу і певної функції, єдність яких і перетворює їх в елементи досліджуваної системи. Ретроспективний аналіз еволюції - від найбільш розвинутих її форм до простих - неминуче зафіксує момент, коли взаємозв'язок між функцією і матеріалом зникне (матеріал перейде в позасистемний вимір). Ідеться саме про ту межу, що й "розіб'є" історію розвитку предмета дослідження на передісторію та власне його історію. Поява досліджуваної функції даного матеріалу стане початком становлення виучуваного предмета.

Висновки та перспективи подалыших досліджень. Педагогіка як галузь наукового знання - керована система, що функціонує в загальному науковому просторі й у межах існування світової спільноти, що розглядаємо як зовнішнє середовище, суперсистему стосовно педагогічної галузі науки. Процес становлення і розвитку педагогічних проблем та явищ відбувається в тісно- 
му взаємозв'язку з усіма елементами означеної суперсистеми, тому кожен період розвитку суспільства i світової науки опосередковано чи безпосередньо впливає на педагогіку й педагогічні явища, наділяючи їх певними ознаками. Зрозуміти появу цих ознак, якісних новоутворень, окремих закономірностей i тенденцій можна лише в контексті розвитку суспільства і науки загалом.

Синергетичний підхід до інтерпретації розвитку педагогічних наук $\mathrm{i}$ явищ допомагає пізнати процес їх становлення і розвитку через поняття синергетики, що дозволяе зрозуміти механізм і внутрішні чинники розвитку предмета дослідження, віднайти початкову межу його періодизації.

Перспективи подальшого дослідження проблеми вбачаємо у визначенні методологічних підходів до вивчення сучасного стану вітчизняної педагогіки як наукової галузі.

\section{СПИСОК ЛІТЕРАТУРИ}

Батлина, Л. В. (1983). Становление и развитие общественного дошкольного воспитания в Украинской ССР (1917-1941 гг.). (Дис. ... канд. пед. Наук). Киев.

Дротянко, Л. Г. (1999). Постнекласична наука в контроверзі модерн - постмодерн. Наука і наукознавство, 1, 36-47.

Князева, Е. Н. (1996). Синергетическая модель эволюции научного знания. Эволюичионная эпистемология: проблемы, перспективы. Москва.

Козловски, П. (1997). Культура постмодерна: общественно-культурные последствия технического развития. Москва : Республика.

Кун, Т. (1977). Структура научных революций. Москва : Прогресс.

Курило, В. С. (2000). Становлення й розвиток системи освіти та педагогічної думки Східноукраїнського регіону в ХХ ст. (Дис. ... д-ра пед. наук). Луганськ.

Лук'янець, В. С., Соболь, О. М. (1998). Філософський постмо- дернізм. Київ : Абрис.

Патнэм, Х. (1998). Философия сознания. Москва : Дом интелектуал. книги.

Попиченко, С. С. (1998). Розвиток теорії і практики дошкільного виховання в Україні (кінець XIX - початок XX ст.). (Автореф. канд. пед. наук). Київ.

Поппер, К. (1975). Логика и рост научного знания. Москва : Прогресс.

Пригожин, И., Стенгерс, И. (1986). Порядок из хаоса. Москва : Прогресс.

Равкин, М. (1984). Методологическая функция историко-педагогических исследований. Советская педагогика, 12, 50-56.

Струманський, В. П. (1996). Методологія і методика історико-педагогічного дослідження. Педагогіка і психологія, 2, 141-146.

Ступарик, Б. М., Моцюк, В. Д. (1995). Ідея національної школи та національного виховання в педагогічній думці Галичини (1872-1939 pp.). Коломия.

Сухомлинська, О. В. (2002). Пері одизація педагогічної думки в Україні: кроки до нового виміру. Педагогічна газета , 10-11, 3-4.

Фейерабенд, П. (1986). Избранные труды по методологии науки. Москва : Прогресс.

Хакен, Г. (2000). Основные понятия синергетики. Москва : Мир.

\section{REFERENCES}

Batlyna, L. V. (1983). Stanovlenye y razvytye obshchestvennoho doshkolnoho vospytanyia v Ukraynskoi SSR (1917-1941 hh.). (Dys. ... kand. ped. Nauk). Kyiv.

Drotianko, L .H. (1999). Postneklasychna nauka v kontroverzi modern - postmodern. Nauka $i$ naukoznavstvo, 1, 36-47.

Kniazeva, E. N. (1996). Synerhetycheskaia model evoliutsyy nauchnoho znanyia. Эvoliutsyonnaia эpystemolohyia: problemy, perspektyvy. Moskva.

Kozlovsky, P. (1997). Kultura postmoderna: obshchestvennokulturnыe posledstvyia tekhnycheskoho razvytyia. Moskva : Respublyka.

Kun, T. (1977). Struktura nauchnokh revoliutsyi. Moskva : Prohress.

Kurylo, V. S. (2000). Stanovlennia y rozvytok systemy osvity ta pedahohichnoi dumky Skhidnoukrainskoho rehionu v XX st. (Dys.... d-ra ped. nauk). Luhansk.

Lukianets, V. S., Sobol, O. M. (1998). Filosofskyi postmodernizm. Kyiv : Abrys.

Patnem, Kh. (1998). Fylosofyia soznanyia. Moskva : Dom yntelektual. knyhy.

Popychenko, S. S. (1998). Rozvytok teorii i praktyky doshkilnoho vykhovannia v Ukraini (kinets XIX pochatok XX st.). (Avtoref. kand. ped. nauk). Kyiv.

Popper, K. (1975). Lohyka y rost nauchnoho znanyia. Moskva : Prohress.

Pryhozhyn, Y., Stenhers, Y. (1986). Poriadok yz khaosa. Moskva : Prohress.

Ravkyn, M. (1984). Metodolohycheskaia funktsyia ys toryko-pedah oh ycheskykh yssledovanyi. Sovetskaia pedahohyka, 12, 50-56.

Strumanskyi, V. P. (1996). Metodolohiia i metodyka istorykopedahohichnoho doslidzhennia. Pedahohika i psykholohiia, 2, 141146.

Stuparyk, B. M., Motsiuk, V. D. (1995). Ideia natsionalnoi shkoly ta natsionalnoho vykhovannia $\mathrm{V}$ pedahohichnii dumtsi Halychyny (1872-1939 rr.). Kolomyia.

Sukhomlynska, O. V. (2002). Periodyzatsiia pedahohichnoi dumky v Ukraini: kroky do novoho vymiru. Pedahohichna hazeta, 10-11, 3-4.

Feierabend, P. (1986). Yzbrannыe trudы po metodolohyy nauky. Moskva : Prohress.

Khaken, H. (2000). Osnovnыe poniatyia synerhetyky. Moskva : Myr.

Стаття надійшла 18.02.2020 p. 